cumspect and prudish." All this is quite right, but is it a description worthy of the great capital of the Continent? The same might be said of all the other countries touched by Mr. R. Brown in this volume. All that he says is quite correct, and we do not find such blunders as are too often found in geographical works. But the necessity of giving the reader a generalisation for the purpose of rendering the book more interesting often leads the author to make such generalisations as give to the reader a most untrue conception of the subject. We must regret that Mr. Brown has been compelled to condense his work in this way, and thus seriously diminish the value of what promised to be a useful and trustworthy compilation.

\section{Phonetik. Zur vergleichenden Physiologie der Stimme} und Sprache. By Dr. F. Techmer. (Leipzig : Engelmann, 1880.$)$

THE excellent work on the Physiology of Language published by Dr. Tecbmer under the above title forms the first volume of an Introduction to the Science of Language, the rest of which is hereafter to appear. We have little hesitation in saying that it is the best résumé that exists at present of what is known about the nature and formation of the sounds we utter.

Dr. Techmer has been well prepared for the task he has undertaken. In the first instance a student of natural science, he next devoted himself to the acquisition of modern European languages, then of languages so remote from ours as Chinese and Sanskrit, and finally to the study of comparative philology. Naturally, however, his earlier studies had inclined him rather to the investigation of the material of speech than to the antiquarian researches of the Indo-Germanists or the psychological inquiries of the school of Steinthal. He brought to the investigation a well-trained mind, an intimate acquaintance with physics, acoustics, and physiology, a wide range of reading, and keen observation. What he has to say, therefore, is well worthy of attention.

The ground he covers is so extensive that in order to bring his work within manageable compass he can do little more than indicate the chief facts, methods of investigation and results which have been arrived at by previous phoneticians, along with copious references and notes. These will enable the reader to follow each particular point into special detail, if he so wish. At the same time Dr. Techmer has not been content with being merely a passive reproducer of the opinions of others. He has carefully tested them wherever it has been possible, and made independent experiments of his own, the results of which be lays before us. Hence his judgments and criticisms are always of value, while the numerous and carefully-drawn illustrations and diagrams which accompany his work leave little to be desired.

$\mathrm{He}$ has done well in not forgetting the comparative method in his treatment of phonetics. Properly to understand the physiology of human speech it is necessary to compare our vocal organs with those of reptiles, mammals, and more especially birds. Jäger has already been struck by the curious relationship that seems to exist between the power of speech and walking on two feet, and has endeavoured to explain it, though not very successfully.

Perhaps the fact that is most brought home to our minds by a study of Dr. Techmer's book is the uncertainty and obscurity that still hang over a large part of phonetics. Experts still differ radically on some of the most fundamental details of the science. This is more especially the case with that side of the science which has to do with acoustics; on the physiological side it lends itself more readily to observation and experiment, and the physiological conditions requisite for the production of particular sounds are consequently much better known. Hence it is that the nature of the consonants is far more accurately determined than that of the vowels, and that it will be long before all the difficulties connected with the formation of the latter are satisfactorily removed. The best means of overcoming them will be a succession of works like this of Dr. Techmer's, at once clear, precise, and thorough.

\section{LETTERS TO THE EDITOR}

[The Editor does not hold himself responsible for opinions expressed by his correstondents. Neither can he undertake to return, or to correspond with the writers of, rejected manuseripts. No notice is taken of anonymous communications.

[The Editor urgently requests correspondents to keep their letters as short as possible. The fressure on his space is so great that it is impossible otherverise to ensure the appearance even of communications containing interesting and nczel facts.]

\section{Medusæ}

IN Mr. H N. Moseley's "Notes by a Naturalist," on the Challenger, p. 404, a curious habit of Medusæ in the Island of Santa Cruz Major, is mentioned, viz. their lying on the tops of their umbrellas, its tentacles directed upwards. I think your readers may be interested to learn that I have frequently noticed Medusæ in a similar position in the West Indies. A few years ago I was quartered for some time at Port Royal, Jamaica, and in the channels between the mangroves I cbserved what I at first thought were Actineæ of large size on the muddy bottom, in about eight feet of water. They were very numerous. I stirred one up with the boat-hook, and was surprised to find it was a Medusa turned npside down. On being disturbed, it lazily con. tracted its umbrella in the usual manner and settled down again in the mud as before. The species was about a foot in diameter of umbrella, and dirty white in colour. I never saw them swim ming in the mangrove creeks, though I was frequently out in a boat, and they were at all times cormon on the bottom, lying as described. Some time afterwards I saw what seemed to be the same species at St. George's Bay, a small island about ten miles from Belize, Honduras. It was lying in the same position on the mud amongst the mangroves, in about four feet of water. I poked several up with a stick, and they slowly swam for a short distance, and again settled down on their umbrellas. I believe it to be really the habit of the species to lie on its back, as it were, and it is interesting to find another kind in the east acting similarly. Margrove swamps are extensive in the vicinity of Singarore, but I have not noticed any Medusæ here in that position, possibly because there is a considerable tide which leaves the mud bare at low water.

I think I have seen the habit noticed in some book, but cannot recollect where.

Fort Canning, Singapore, June 28

H. ARCHER

\section{Two Kinds of Stamens with Different Functions in the same Flower}

THE following extract from a letter lately received from my brother Fritz Muiller (of Blumenau, Prov. St. Catharina, Brazil) contains so new and curious an observation that it will probably interest the botanical readers of this journal.

"A species of Heeria (Melastomaceæ), which is not indigenous here, begins in my garden now to open its beautiful red flowers,

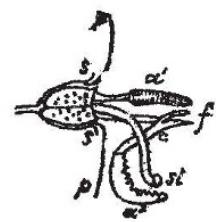

Flower of Heeria spec., longitudinally dissected. $s$, sepals; $\beta$, petals; $\boldsymbol{\alpha}^{\mathrm{r}}$, one of the conspicuous yellow anthers which attract the insects; $a^{2}$ one of the inconspicuous red anthers, which powder the insects with pollen; $c$, connective of this anther ; $f$, fork of this connective; st, stigma.

remarkable for having two kinds of differently coloured anthers. The four petals spread in a perpendicular plane; the yellow anthers $\left(a^{1}\right)$ of the four shorter filaments, closely pressed together, project from the middle of the flower ; their bright yellow strikingly contrasts with the violet-shining light red of the corolla; the longer anthers $\left(a^{2}\right)$ are red, like the filaments, and the very long connective $(c)$, which is lengthened beyond the point of insertion 